\title{
The first authenticated record of Pygmy Killer Whale (Feresa attenuata Gray 1874) in Mozambique; has it been previously overlooked?
}

\author{
Gary A. Allport ${ }^{1 *}$, Christopher Curtis ${ }^{2}$, Tiago Pampulim Simões ${ }^{3}$ and Maria J. Rodrigues ${ }^{4}$
}

\begin{abstract}
Background: The cetacean fauna of the poorly-studied waters off eastern Africa is still being described. Information on the cetacean species occurring in specific range states is important for understanding their geographical distribution ranges and for implementing national and international conservation and management measures. This report presents the first authenticated record of the Pygmy killer whale in Mozambican waters and the first record on the eastern coast of southern Africa since 1970.

Methods: As a part of regular informal surveys for birds and other marine life from Maputo, Mozambique, three

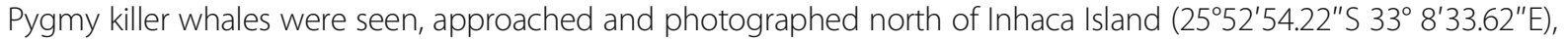
on 23 April 2017.

Results: The animals were seen interacting on the surface for $35 \mathrm{~min}$, travelling at ca. $1 \mathrm{~km} / \mathrm{h}$ along the shelf edge in water $235 \mathrm{~m}$ deep. All three animals had been overlooked by the authors earlier in the day, misidentified as Spinner dolphins (Stenella longirostris).

Conclusion: This is the first authenticated record of Pygmy killer whale in Mozambican waters and the first recent record on the eastern coast of southern Africa since 1970, emphasising the lack of knowledge of offshore marine biodiversity in Mozambique. Previous reported records of the species in Mozambique lie outside Mozambique Exclusive Economic Zones or lack evidence. The species should be included in relevant conservation planning. Available identification material focusses on the separation of this species from Melon-headed whale (Peponocephala electra) and fails to note the great similarities of this species with smaller dolphins. At-sea observers are encouraged to consider this species when identifying 'dolphins'. Pygmy killer whales are easily overlooked.
\end{abstract}

Keywords: Pygmy killer whale, Feresa attenuata, Mozambique, First record, Identification

\section{Background}

The biodiversity of the national marine Exclusive Economic Zones (EEZs) of eastern southern Africa is generally poorly known and documented, especially in offshore areas, mostly due to the logistical and financial challenges of working in the region as well as the lack of local scientists. The cetacean fauna of Tanzania has recently been reviewed confirming 20 cetacean species (Brualik, Kasuga, Wittich,

\footnotetext{
* Correspondence: Gary.allport@birdlife.org

${ }^{1}$ BirdLife International, David Attenborough Building, Pembroke Street,

Cambridge CB2 3QZ, UK

Full list of author information is available at the end of the article
}

Said Shahib Said, Macaulay, Gordon and Gillespie: A Nationwide survey of Cetaceans in Tanzania. WCS Report, unpublished) although several of these species have only been verified on few occasions. The cetacean fauna of Mozambique has barely been described with no formal listing. The best known marine fauna in the region is South Africa where the cetaceans are relatively well-documented (Stuart and Stuart 2007; Best 2007).

National conservation legislations apply to EEZs and rely on an understanding of the species occurring therein for policy implementation. Many cetaceans are highly-mobile and may travel across multiple range 
states and international conservation agreements have been developed, such as The Convention on Migratory Species and CITES, which rely on the cooperation, participation, and coordination of each of the range states, and so the confirmed list of species included under such agreements is fundamental to their implementation too.

Observations of cetaceans within these relatively poorly known areas also offer opportunities to better document the biology of little-known species, with potential to advance knowledge of identification, habitat preferences and behaviour.

Here we present details of an observation of three Pygmy Killer Whales (Feresa attenuata Gray 1874) in Mozambique in April 2017. The animals were recorded on an informal pelagic trip from Maputo, and constitute the first authenticated record for Mozambique.

The Pygmy killer whale is a rare and poorly known cetacean (Donahue and Perryman 2002; Ross and Leatherwood 1994; McSweeney et al. 2009). The species was only known from two skulls collected in the 1800s until the 1950s when a single animal was harpooned by a blackfish-boat from Taiji, Japan (Yamada 1954). Subsequently there have been a scattering of records in tropical and subtropical waters, but particularly in the eastern tropical Pacific, the Hawaiian Archipelago, off Sri Lanka, Taiwan and Japan. Records have mostly been gathered opportunistically from strandings, bycatch and deliberate trapping, with sight records more recently as the species has become better known.

There have been periodic reviews collating records of the species in the eastern Pacific (Van Waerebeek and Reyes 1988), Atlantic (Caldwell and Caldwell 1971) and Indian Oceans (Leatherwood et al. 1991) as well globally (Caldwell and Caldwell 1971; Brownell, Yao, Lee and Wang: Worldwide review of Pygmy Killer Whales, Feresa attenuata, mass strandings reveals Taiwan hotspot, unpublished; Jeyabaskaran et al. 2011). A small number of animals have been individually photo identified (McSweeney et al. 2009) and satellite tagged (Baird et al. 2011) off Hawai'i. The species remains, however, extremely little known and is classified as 'Data Deficient' by the International Union for Conservation of Nature (IUCN) (Taylor et al. 2008) and whilst it can occur locally at a density of 4.49 animals $1000 \mathrm{Km}^{-2}$ (within the Hawai'i Main Island strata; Barlow 2006) it is considered thinly distributed and rare globally (Donahue and Perryman 2002; McSweeney et al. 2009). The species is listed in Appendix II of CITES.

Record gathering has not only been limited due to infrequent encounters but the Pygmy killer whale is also difficult to identify. The species is very similar to two other 'Blackfish' the Melon-headed Whale (Peponocephala electra) and, to a lesser extent, the False killer whale (Pseudorca crassidens) and there has been re-identification of animals in the photographic record (Siciliano et al. 2007; Baird 2010; Siciliano and Brownell 2015). The mainstream identification guides have focussed on providing informative, helpful and accurate information on the separation of these three similar Blackfish species (Carwardine 1995; Shirihai et al. 2006) aiding correct identification at-sea significantly.

Pygmy killer whales are mostly recorded in warm, deep waters $>250 \mathrm{~m}$ and only close to shore around oceanic islands (Donahue and Perryman 2002; McSweeney et al. 2009). Group size is mostly less than 50 animals and small groups of 3-10 animals are regularly encountered. Evidence of group cohesion and faithfulness has been found with individually identified animals cohorting for more than 21 years off Hawai'i Main Island (McSweeney et al. 2009).

The species is known from the Indian Ocean with a relatively well known population off Sri Lanka and a scattering of records across the region from the Gulf of Aden in the northwest, Indonesia in the east, and as far south as southern Africa (Leatherwood et al. 1991). On the Indian Ocean coast of Africa the species is known from a short series of records in South Africa (Best 1970; Findlay et al. 1992) and one record from the French Southern Ocean Territories (GBIF Backbone Taxonomy 2016). The species is listed as occurring in Madagascar (Taylor et al. 2008) but there is no published supporting evidence for this.

The existing knowledge of the distribution, ecology and behaviour of this species has come mostly from opportunistic encounters so it is important that all observations are documented to broaden our knowledge.

\section{Methods}

Fourteen pelagic trips have been undertaken from Maputo since May 2011 looking for seabirds, sea mammals and other marine life. The trips last a full day and the route varies with local conditions but always range across Maputo Bay and then out over the shelf to the east into water of $250-750 \mathrm{~m}$ depth. A global positioning system is used to record the track and photos are taken of all wildlife of interest.

On 23 April 2017 the route plan was to depart at 05.30 am Central Africa Time (CAT) steam quickly to the north of Inhaca Island, then head more slowly eastwards out into deeper waters looking for birds and other wildlife, chum for seabirds and then head southward along the $400 \mathrm{~m}$ depth contour before returning back to Maputo later in the day. The weather and sea conditions were unusually favourable with $<1 \mathrm{~m}$ swell, light winds $<5$ knots and sea state 2 all day.

\section{Results}

At 06.40 am CAT whilst steaming outbound northwards GA spotted two or more small cetaceans logging on the 
surface at least $\mathrm{c} 1.5 \mathrm{~km}$ distant eastwards from the planned route. They appeared to be Spinner dolphins (Stenella longirostris), a species seen on most trips (9 out of 14), and often common. The animals were not approached as they were not noteworthy enough to warrant a significant deviation from the planned route. GA noted, however, that the animals were quite dark in colour - attributed to the early morning light at the time - and were resting stationary on the surface, unusual for Spinner dolphins.

At 12.56 CAT the return route took the vessel $4 \mathrm{~km}$ further eastward of the location of the earlier dolphin sighting when three small cetaceans were spotted $\left(25^{\circ}\right.$ 52'54.22"S 3308'33.62"E; Fig. 1) and called as Spinner dolphins by GA and others. A gentle approach was made as the animals were resting on the surface. GA was sure they were the same animals seen six hours earlier. They were moving slowly, socialising and GA quickly became unsure of the identification, noting that the characteristic bottle of a dolphin had not been visible when the animals turned on the surface. Once within $100 \mathrm{~m}$ one animal spy hopped showing a rounded head shape and no bottle (Fig. 2).

The three animals (Fig. 3) were identified as Pygmy killer whales based on small size, rounded head shape, white lips and rounded front flipper tips (Fig. 4) (Carwardine 1995). In addition the white to pinkish white belly (Fig. 5) and small group size supported the identification. Efforts were made to photograph and video [see Additional file 1] the animals, and a careful approach yielded a friendly encounter.

The sighting continued for 35 min during which time the three animals moved $0.57 \mathrm{~km}$ from the initial location, slowly $(0.98 \mathrm{~km} / \mathrm{h})$ southwards staying on the surface interacting with each other intensively, mostly ignoring the boat, but on two occasions approaching the bow inquisitively within 2-3 $\mathrm{m}$. Water temperature was $25.8^{\circ} \mathrm{C}$ and depth at the location was $235 \mathrm{~m}$ on the shelf edge.

There were three animals, two of which were similar in size, estimated at c. $2 \mathrm{~m}$ length. One animal was more lightly built, darker in colour with a smaller dorsal fin (Fig. 6). It was estimated to be $5-10 \%$ smaller than the other two. All three animals showed characteristic scarring (Fig. 4). The plate in Shirihai et al. (2006) suggests that such scarring is characteristic of male Pygmy killer whales, although no supporting evidence is given.

The three animals exhibited an interesting behaviour, staying within very close proximity of each other, often surfacing synchronously and bunching up tightly. The group would come to a dead stop and at which time one animal would clamber over the top of the other two, starting from a parallel position and crossing the other two animals on or near the surface, which made no particular attempt to move. The animal would finish the manoeuvre crossing to the other

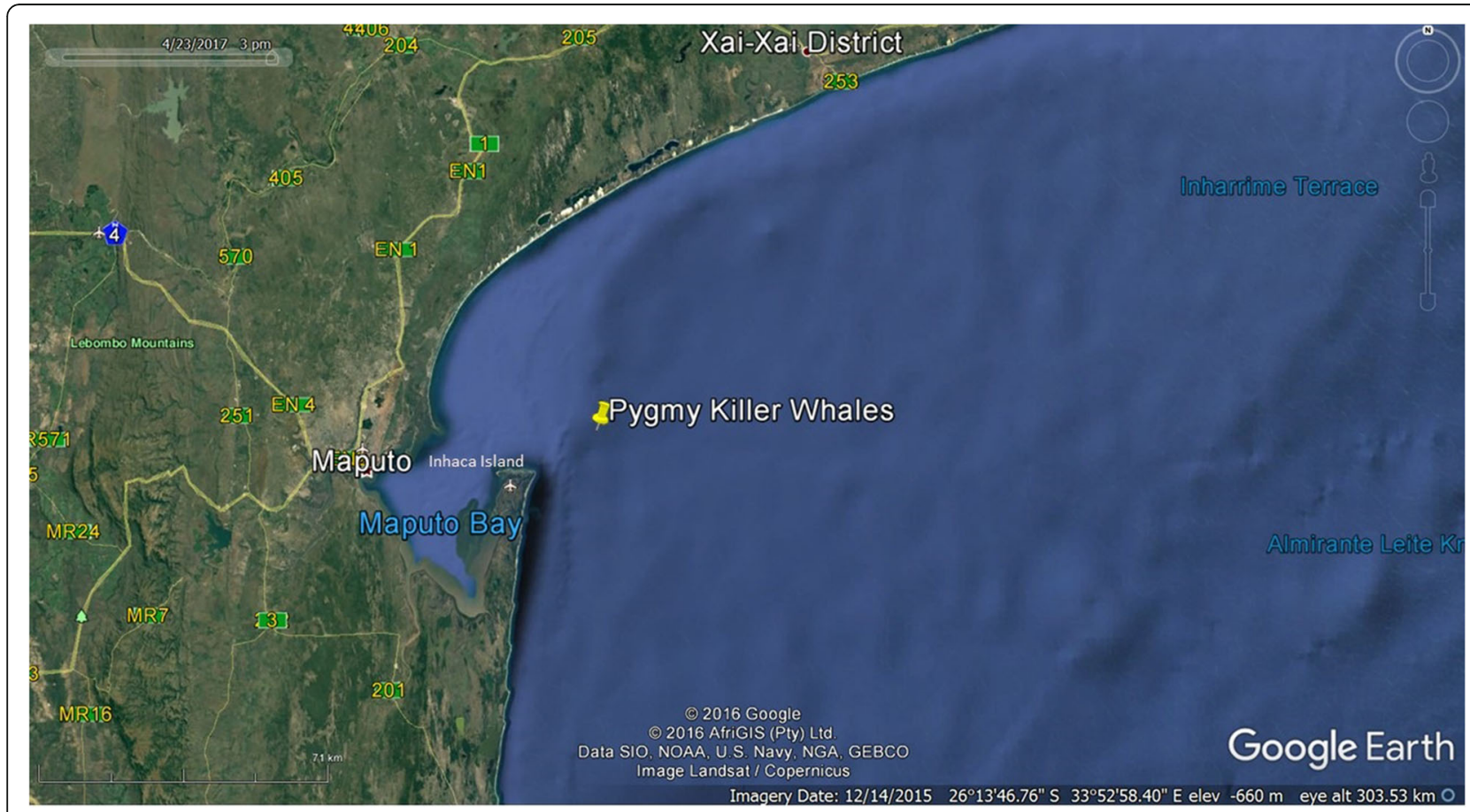

Fig. 1 Map of location of Pygmy killer whales Feresa attenuata off Maputo, Mozambique 23 April 2017. Google Earth copyright attribution as per image 


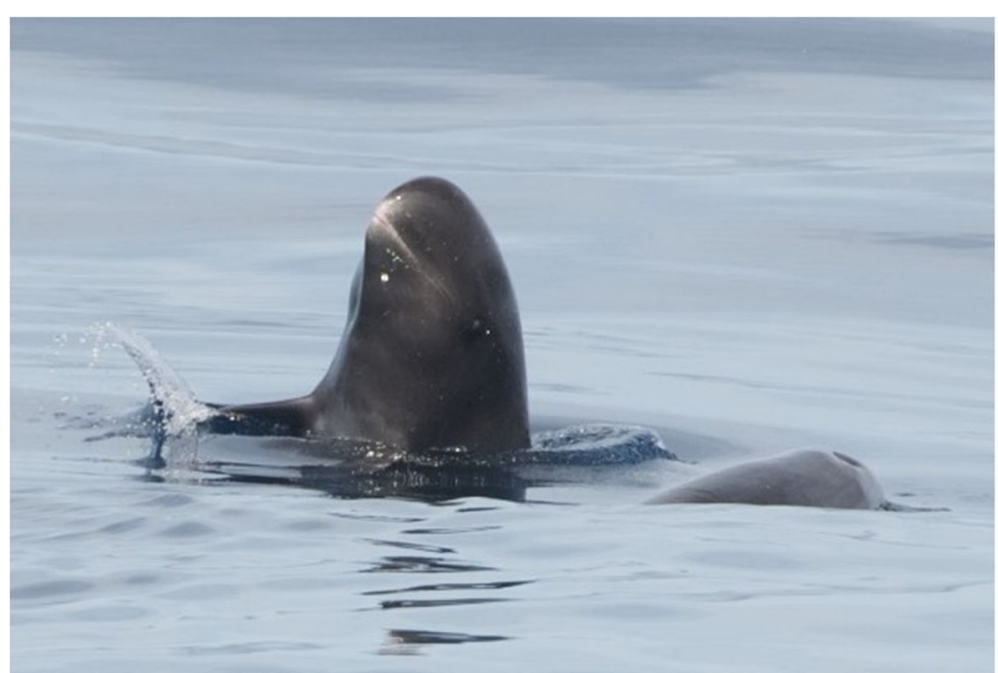

Fig. 2 Pygmy killer whale Feresa attenuata off Maputo, Mozambique 23 April 2017. Half-breaching, note pale snout. Photo C. Curtis

side of the other two animals at or near to the rear of their dorsal fins. An additional movie file shows this behaviour [see Additional file 1]. Close examination of the video showed that it was the smaller darker animal that was undertaking this cross-over behaviour.

The decision was taken to leave the group of whales after 35 min. Afterwards a group of 5-6 Spinner Dolphins were seen $7 \mathrm{~km}$ further to the south west, in typical mode, moving quickly and not seen well, and a group of c15 Bottle-nosed Dolphins Tursiops truncatus were seen $11 \mathrm{~km}$ to the south west which were boat friendly and rode the bow for several minutes.

The photos and videos of the Pygmy killer whales were shared with experts who confirmed the identification (R. Baird, A. Martin in litt. 2017.).

\section{Discussion}

\section{Records in Mozambique}

In a collation of records worldwide Jeyabaskaran et al. (2011) cites two records of Pygmy killer whale in Mozambique. However, both these records are cited as from Leatherwood et al. (1991) the first of which, of nine individuals, appears to be a misinterpretation of the data table in Leatherwood et al. (1991) - there being no record of nine individuals described therein - and the second record of 25-30 animals seen on $6^{\text {th }}$ July 1985 (reported by J. Beadon to S. Leatherwood and not assigned to a country) is from a location that lies within French Southern Ocean Territories off Europa Island and not in the Mozambique EEZ. There is a second record on $13^{\text {th }}$ June 1985 from the same locality reported as

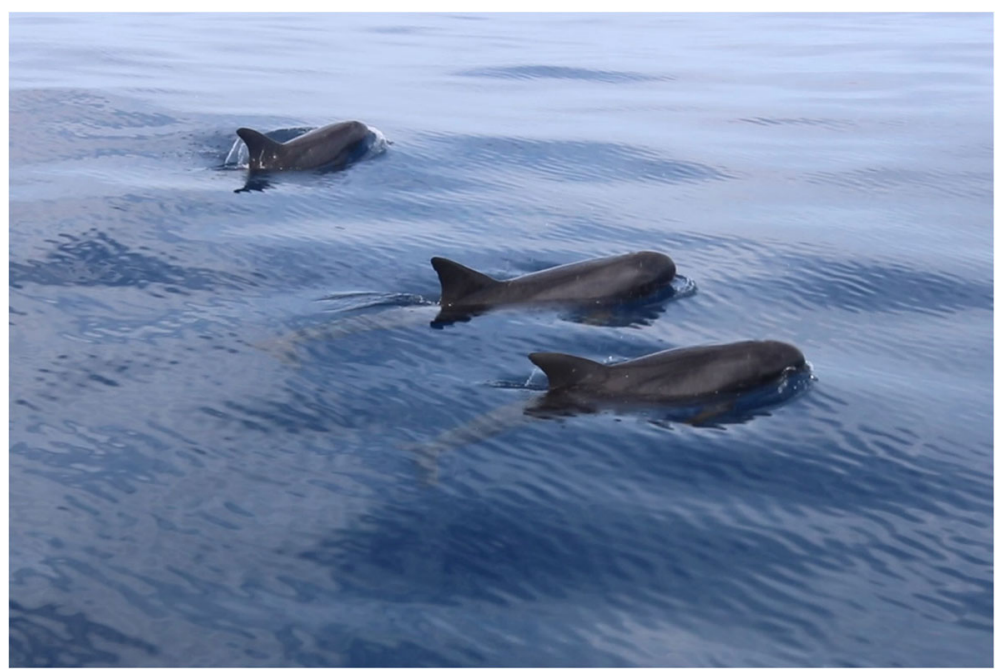

Fig. 3 Three Pygmy killer whales Feresa attenuata off Maputo, Mozambique 23 April 2017. Note synchronous surfacing [see video in Additional file 1]. Photo (video grab) G. Allport 


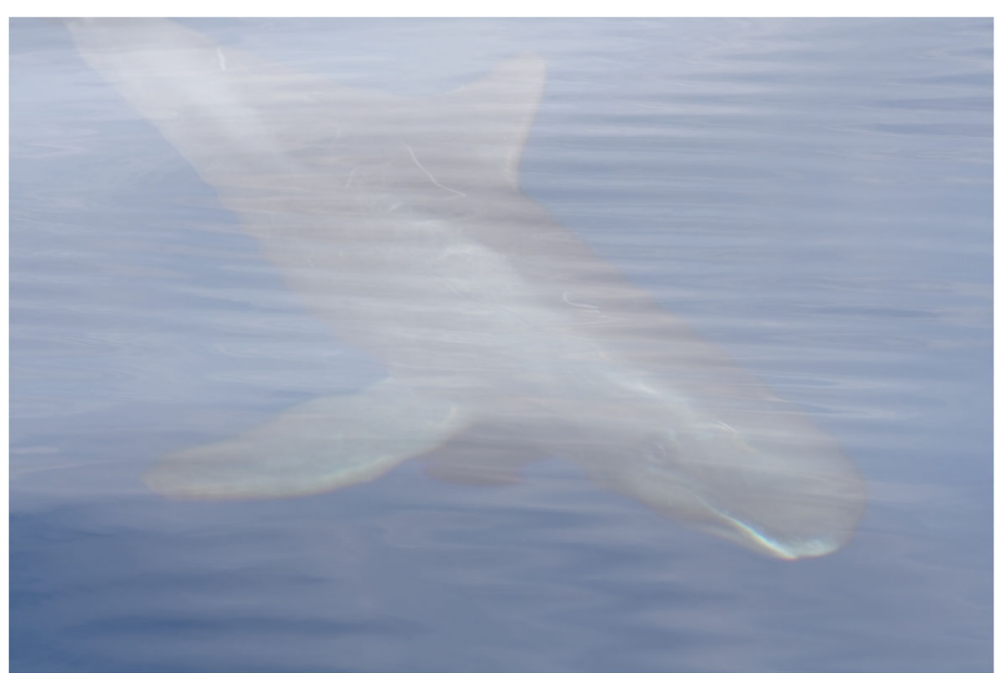

Fig. 4 Pygmy killer whale Feresa attenuata off Maputo, Mozambique 23 April 2017. Note white lips and snout, scratches on body as well as rounded tips to pectoral fins. Photo $C$. Curtis

a gillnet catch in Leatherwood and Reeves (1989) not reported in Jeyabaskaran et al. (2011). Both these latter records are within the Mozambique Channel but are not in Mozambique.

The only other possible record in Mozambique is of an animal photographed at Pemba, Mozambique which is undated and not formally published (Reichelt and Baines 2012) although looks very likely to be a Pygmy killer whale.

The sighting reported herein is therefore the first authenticated record of this rare cetacean for Mozambique and is of significance in flagging both the limited knowledge of Mozambique's marine EEZ and the likely significant marine biodiversity therein.

Tagging studies of two animals in Hawai'i showed Pygmy killer whales travelled at an average speed of $3.1 \mathrm{~km} / \mathrm{h}$ and ranging up to 79 and $106 \mathrm{~km}$ straight line distance in 10 and 21 days of tagging respectively. Both animals stayed within close proximity of the island along the shelf edge (Baird et al. 2011). Recent sighting reports from Australia also found four groups of this species on the shelf edge within a relatively finite area (Owen and Donnelly 2014). It is also worth stressing that within the known home range of the resident Hawai'i group, sightings were only reported once per 35 observation days (McSweeney et al. 2009). It is therefore quite possible that a small group of these rare animals are resident in this area of southern Mozambique and have passed unnoticed until now.

Shirihai et al. (2006) report the species as showing boat shyness and if this were to be the case then it would compound the problems of confirming the presence of this species. However, the evidence for this is lacking and the animals in our encounter were not boat shy, indeed were mildly inquisitive.

It is worth clarifying the other records from the Indian Ocean coast off South Africa here. The four records reported by Ross (1984) are summarised in Table 1. Leatherwood et al. (1991) may not have had access to Ross (1984) as their summary table only includes two records

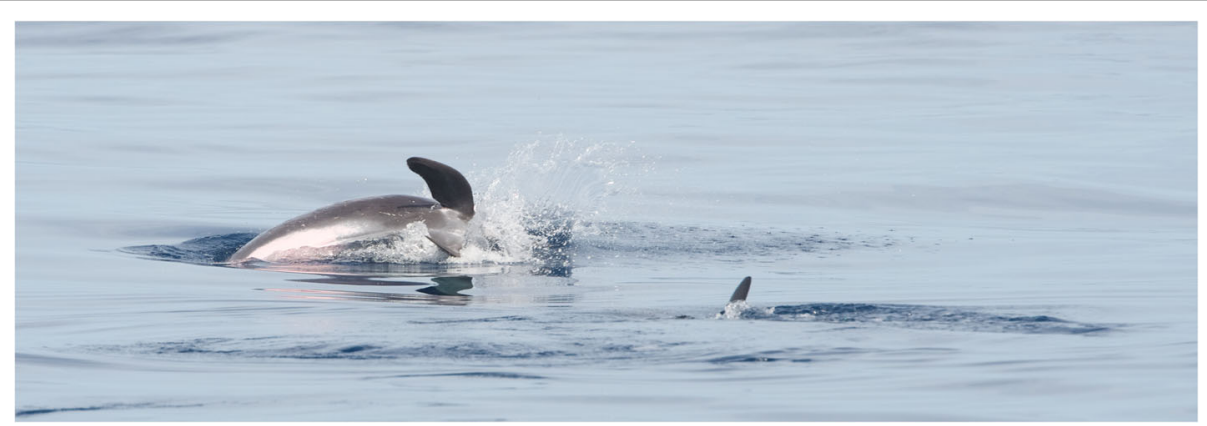

Fig. 5 Pygmy killer whales Feresa attenuata off Maputo, Mozambique 23 April 2017. Note pinkish white rear belly and rounded tips to pectoral fins. Photo C. Curtis 


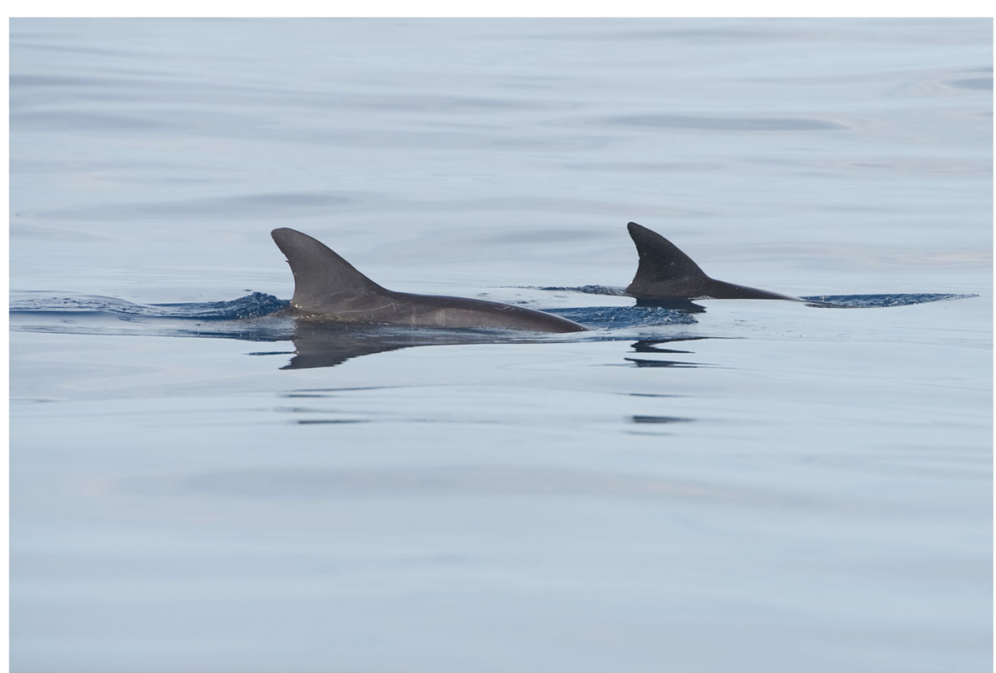

Fig. 6 Pygmy killer whales Feresa attenuata off Maputo, Mozambique 23 April 2017. Showing smaller darker invidual (rear, right). Photo C. Curtis

from 1968/9 with question marks on an undated record from Port Elizabeth. Jeyabaskaran et al. (2011) follows Leatherwood et al. (1991) but includes a record from 1974 attributed to Ross (1979) - the latter is a study of the Pygmy and Dwarf sperm whales (Kogia spp.) and makes no reference to Pygmy killer whale so this record should be discounted. Whilst not in the Indian Ocean, it should also be noted that Jeyabaskaran et al. (2011) incorrectly categorise a record of this species from Namibia (Oosthuizen 2004) in their tabulation as from South Africa.

It is notable that there have been no records from the region since 1970 even with greater coverage by knowledgeable observers. Three of the four historical records from the region are in April/May, as is the record herein. The Pygmy killer whale is considered a warm water species (Donahue and Perryman 2002) and it may be that the species is a wanderer to the region's seas in small groups when water temperature and prey availability are suitable. A warm water incursion was attributed to the first record of Pygmy killer whale in the Gulf of California in
2014 (Elorriaga-Verplancken et al. 2016). However, water temperatures off Maputo were not notably high at the time of the observation (GA pers. obs., http://www.fishtrack. com/fishing-charts/south-africa-east_62420) but it may be that cooler water temperatures to the south mean that the species only wanders further in to the subtropics when warmer water incursions take place.

\section{Identification}

The identification of Pygmy killer whale, as with all cetaceans, has been greatly advanced with the production of advanced field guides. Carwardine (1995) and Shirihai et al. (2006) are the two most useful guides for the Mozambique Channel region, and both carry high quality illustrations of the Pygmy killer whale and clear indication of the key features for separating it from the very similar Melon-headed whale at sea. However, both guides fail to emphasise the similarity of Pygmy killer whale to small dolphins; Shirihai et al. (2006) says "could be overlooked among dolphins". With limited space in their publications it is clear that focus of the

Table 1 Records of Pygmy killer whale Feresa attenuata in the Indian Ocean coast of southern Africa

\begin{tabular}{|c|c|c|c|c|c|}
\hline Date & Location & Type & Number & Reference & Specimen no \\
\hline 06.03.1957 & $\begin{array}{l}\text { Schoemakerskop, } \\
\text { Port Elizabeth, South Africa }\end{array}$ & Skull specimen & 1 & Ross 1984, Findlay et al. 1992 & PEM 1514/09 \\
\hline 16.05.1968 & Richard's Bay, South Africa & $\begin{array}{l}\text { Stranding, specimen } \\
\text { (rostrum mandible and teeth) }\end{array}$ & 1 & $\begin{array}{l}\text { Bass 1969; Best 1970; Ross 1984; } \\
\text { Leatherwood et al. 1991; } \\
\text { Findlay et al. 1992; } \\
\text { Jeyabaskaran et al. } 2011\end{array}$ & SAM 35601 \\
\hline 16.08 .1969 & $\begin{array}{l}\text { At sea off Port St Johns, } \\
31^{\circ} 38^{\prime} S, 30^{\circ} 07^{\prime} E \text {, South Africa }\end{array}$ & At sea sighting & 11 & $\begin{array}{l}\text { Best 1970; Ross 1984; } \\
\text { Findlay et al. 1992; } \\
\text { Leatherwood et al. 1991; } \\
\text { Jeyabaskaran et al. } 2011\end{array}$ & \\
\hline 09.04 .1970 & $\begin{array}{l}2 \mathrm{~km} \text { east of Woody Cape, nr. } \\
\text { Port Elizabeth, South Africa }\end{array}$ & Stranding, specimens & 2 & Ross 1984; Findlay et al. 1992 & $\begin{array}{l}\text { PEM 1515/41 \& } \\
1515 / 42\end{array}$ \\
\hline
\end{tabular}


identification material should be on the sibling species of Blackfish most similar to Pygmy killer whale. However, even experienced marine mammal observers are advised to consider this species whenever dolphins are found at-sea and especially where the frontal head shape of the animals encountered remains unseen. It is worth stressing that unlike Melon-headed whale, Pygmy killer whales do not normally lift the full face above the water as they surface to breathe (Shirihai et al. 2006 and this observation) so it is not easy to confirm the lack of a bottle. Furthermore, in calmer waters the small bow wave pushed in front of the face looks like a bottle from a distance [see Additional file 1]. In our encounter, the first confirmation of the head shape was when an animal breached, and high quality digital photos were examined closely. The frontal area of the head is more bulbous and melon-shaped than in the confusingly named Melon-headed whale but the bulbous head shape is still not very evident when the Pygmy killer whales are moving and especially when heading away from the observer, as is very often the case in at-sea conditions. Small dark dolphins should always be checked carefully with Pygmy killer whale in mind.

\section{Conservation issues}

IUCN lists the Pygmy killer whale as Data Deficient (Taylor et al. 2008). In Mozambique, there are a number of pieces of legislation directly and indirectly applicable. All whales are protected by the Recreational and Sports Fishing Regulation (Decree 51/99 of 31 August 1999) but only for recreational and sports fishers. The international trade of this species is controlled through Appendix II of CITES, of which Mozambique is signatory. The Indian Ocean Tuna Commission, of which Mozambique is also signatory, only requests that in the case that cetaceans are caught, then the incident should be duly reported. The species is not listed by Convention of Migratory Species.

The record of Pygmy killer whale reported here lies close (7 nautical Miles [nM]) to the northern boundary of one of Mozambique's premier marine protected areas, the Ponta do Ouro Partial Marine Reserve, which includes Inhaca Island and the offshore waters up to $3 \mathrm{nM}$. Whilst it is possible that the species occurs within the reserve, the shelf edge marine habitat that this species frequents is on the very seaward boundary of the reserve.

There have been reports in Hawai'i of Pygmy killer whales showing signs of fishing line cuts to the head and of hooks from long lining gear embedded in the mouth (Cascadia Research Collective 2017). This species is therefore likely to be vulnerable to long lining activities targeting billfish and tuna in Mozambican waters.

Evidence from stranded individuals of several similar species indicates that they have swallowed discarded plastic items, which may eventually lead to death (e.g. Scott et al. 2001); this species may also be at risk.

Pygmy killer whale, like beaked whales, is likely to be vulnerable to loud anthropogenic sounds, such as those generated by navy sonar and seismic exploration (Cox et al. 2006) and have been a part of multi-species unusual stranding events in Taiwan (Wang and Yang 2006). There is some evidence that this is a potential problem in Mozambique (Raba 2006).

This species does not appear to be particularly abundant anywhere that it has been sighted. In Hawai'i, subpopulations appear to be small (McSweeney et al. 2009), and this, along with their limited movements (Baird et al. 2011), suggests the species may be particularly vulnerable to human impacts regionally (Taylor et al. 2008).

\section{Conclusions}

This is the first authenticated record of Pygmy killer whale in Mozambican waters emphasising the lack of knowledge of offshore marine biodiversity in Mozambique and the potential for the country to hold as yet undiscovered rare marine biodiversity. The species should be included in relevant conservation planning.

Available identification material focusses on the separation of Pygmy killer whale from Melon-headed Whale and fails to note the similarities of this species with other smaller dolphins. At-sea observers are encouraged to consider this species when identifying any 'dolphins' they encounter.

\section{Additional file}

Additional file 1: Video of Pygmy Killer Whales (Feresa attenuata) off Inhaca Island, Maputo, Mozambique 23 April 2017. Video G. Allport and C. Curtis. (MP4 $147135 \mathrm{~kb}$ )

\section{Abbreviations \\ CAT: Central Africa Time; CITES: Convention on International Trade in Endangered Species; E: East; EEZ: Exclusive Economic Zone; GPS: Global positioning system; IUCN: International Union for the Conservation of Nature; km: kilometres; km/h: kilometres per hour; m: metres; nM: nautical Miles;} S: South

\section{Acknowledgements \\ Thanks go to all members of the trip that made it viable, including Tim Petersen and Manuel Costeira da Rocha. Anouk llangakoon, Robin Baird, Gill Braulik, Tim Collins, Tony Martin, Hugo Rainey, Melinda Rekdahl and Dylan Walker helped with identification, information sources and gave other advice.}

\section{Funding \\ World Wildife Fund - Mozambique covered the costs of publication of this paper.}

Availability of data and materials

Data sharing is not applicable to this article as no datasets were generated or analysed during the current study. 


\section{Authors' contributions}

GA led the research trip, gathered basic trip data, identified the animals in the field, took photographs and video, undertook literature review and wrote the paper. CC took photographs and video. TPS spotted the animals and skippered the boat in a cetacean friendly manner. MJM wrote the section on conservation in Mozambique. All authors read and approved the final manuscript.

\section{Competing interests}

The authors declare that they have no competing interests.

\section{Consent for publication}

Not applicable.

\section{Ethics approval}

Not applicable.

\section{Publisher's Note}

Springer Nature remains neutral with regard to jurisdictional claims in published maps and institutional affiliations.

\section{Author details}

${ }^{1}$ BirdLife International, David Attenborough Building, Pembroke Street, Cambridge CB2 3QZ, UK. Casa 31, Condominio Sommerschield II, Rua do Palmar No. 817, Maputo, Mozambique. ${ }^{3}$ Number One Serviços Maritimos, Av. Karl Marx nr. 478, 6 andar, Maputo, Mozambique. ${ }^{4}$ WWF Mozambique, Av. Kenneth Kaunda 1174, Maputo, Mozambique.

Received: 18 May 2017 Accepted: 24 May 2017

Published online: 08 June 2017

\section{References}

Baird RW. Pygmy Killer Whales (Feresa attenuata) or False Killer Whales (Pseudorca crassidens)? Identification of a group of small cetaceans seen off Ecuador in 2003. Aquat Mamm. 2010;36(3):326-7. http://dx.doi.org/10.1578/ AM.36.3.2010.326

Baird RW, Schorr GS, Webster DL, McSweeney DJ, Hanson MB, Andrews RD. Movements of two satellite-tagged pygmy killer whales (Feresa attenuata) off the island of Hawai'i. Mar Mamm Sci. 2011;E332-7. http://dx.doi.org/10.1111/j. 1748-7692.2010.00458.x

Barlow J. Cetacean abundance in Hawaiian waters estimated from a summer/fall survey in 2002. Mar Mamm Sci. 2006;22:446-64.

Bass A. A rare whale stranded in Zululand. Bull S Afr Assoc Mar Bio Res. 1969;7:36 Best PB. Records of the Pygmy killer whale, Feresa attenuata, from Southern Africa, with notes on behaviour in captivity. Ann S Afr Mus. 1970;57:1-14.

Best PB. Whales and Dolphins of the Southern African Subregion. Cambridge, United Kingdom \& Cape Town, South Africa: University Press; 2007.

Caldwell DK, Caldwell MC. The Pygmy killer whale, Feresa attenuata, in the western Atlantic, with a summary of world records. J Mammal. 1971;52:206-9.

Carwardine M. Whales, dolphins and porpoises. London: Dorling Kindersley; 1995.

Cascadia Research Collective. Pygmy killer whales in Hawai'i. http://www. cascadiaresearch.org/hawaiian-cetacean-studies/pygmy-killer-whales-hawaii. Accessed 16 May 2017

Cox TM, Ragen TJ, Read AJ, Vos E, Baird RW, Balcomb K, Barlow J, Caldwell J, Cranford T, Crum L, D'Amico A, D'Spain A, Fernández J, Finneran J, Gentry R, Gerth W, Gulland F, Hildebrand J, Houser D, Hullar T, Jepson PD, Ketten D, Macleod CD, Miller P, Moore S, Mountain D, Palka D, Ponganis P, Rommel S, Rowles T, Taylor B, Tyack P, Wartzok D, Gisiner R, Mead J, Benner L. Understanding the impacts of anthropogenic sound on beaked whales. J Cetacean Res Manag. 2006;7(3):177-87

Donahue MA, Perryman WL. Pygmy Killer Whale (Feresa attenuata). In: Perrin WF, Würsig B, Thewissen JGM, editors. Encyclopedia of marine mammals. San Diego: Academic; 2002. p. 1009-10.

Elorriaga-Verplancken FR, Rosales-Nanduca H, Paniagua-Mendoza A, MartínezAguilar S, Nader-Valencia AK, Robles-Hernández R, Gómez-Díaz F, Urbán RJ. First Record of Pygmy Killer Whales (Feresa attenuata) in the Gulf of California, Mexico: Diet Inferences and Probable Relation with Warm Conditions During 2014. Aquat Mamm. 2016:42:20-6.

Findlay KP, Best PB, Ross GJB, Cockcroft VG. The distribution of small Odontocete Cetaceans off the coasts of South Africa and Namibia. S Afr J Mar Sci. 1992; 12:237-70. doi:10.2989/02577619209504706.
GBIF Backbone Taxonomy. GBIF Secretariat. Checklist Dataset. 2016. https://doi. org/10.15468/39omei Accessed via GBIF.org on 17 May 2017.

Gray JE. Description of the skull of a new species of dolphin (Feresa attenuata). Annu Mag Nat Hist. 1874:4:238-9.

Jeyabaskaran R, Vivekanandan PS, Yousuf KSSM. First record of Pygmy killer whale Feresa attenuata Gray, 1874 from India with a review of their occurrence in the World Oceans. J Mar Biol Assoc India. 2011;53:208-17.

Leatherwood S, Reeves RR. Marine mammal research and conservation in Sri Lanka 1985-1986. UNEP Mar Mamm Tech Rep. 1989:1:1-138.

Leatherwood S, Mcdonald D, Prematunga WP, Girton P, llangaakoon A, Mcbrearty D. Records of the "Blackfish" (Killer, False Killer, Pygmy Killer and Melon-headed Whales) in the Indian Ocean. UNEP Mar Mamm Tech Rep. 1991;3:33-65.

McSweeney DJ, Baird RW, Mahaffy SD, Webster DL, Schorr GS. Site fidelity and association patterns of a rare species: Pygmy killer whales (Feresa attenuata) in the main Hawaiian Islands. Mar Mamm Sci. 2009;25:557-72.

Oosthuizen WH. Progress report on cetacean research, January 2004 to December 2004, with statistical data for the calendar year 2004. 2004. http:// www.iwcoffice.org/_documents/sci_com/2005progreports/SC-57ProgRepSouthAfrica.pdf. 17 May 2017.

Owen K, Donnelly D. The most southerly worldwide sightings of Pygmy killer whales (Feresa attenuate). Mar Biodivers Rec. 2014;7:e46. doi:10.1017/ S1755267214000463.

Raba N. Mass stranding of bottlenose dolphins in Mozambique. MARMAM. 2006. https://lists.uvic.ca/pipermail/marmam/2006-October/000704.html. Accessed 17 May 2017.

Reichelt M, Baines M. Pygmy killer whale breaching. 2012. http://www.wildscope. com/ocean-life/Mozambique.html. 17 May 2017.

Ross GJB. Records of Pygmy and Dwarf sperm whales, genus Kogia, from Southern Africa, with biological notes and some comparisons. Ann Cape Prov Mus (Nat Hist). 1979:11:259-337.

Ross GJB. The smaller cetaceans of the south east coast of southern Africa. Ann Cape Prov Mus. 1984;15:173-410.

Ross GJB, Leatherwood S. Pygmy killer whale Feresa attenuata Gray, 1874. In: Ridgway SH, Harrison RJ, editors. Handbook of marine mammals. 5th ed. London: Academic; 1994. p. 387-404.

Scott MD, Hohn AA, Westgate AJ, Nicolas JR, Whitaker BR, Campbell WB. A note on the release and tracking of a rehabilitated Pygmy sperm whale (Kogia breviceps). J Cetacean Res Manag. 2001;3:87-94.

Shirihai H, Jarrett B, Kirwan GM. Whales, dolphins, and other marine mammals of the world. Princeton: Princeton University Press; 2006.

Siciliano S, Brownell RL. Getting to know you: Identification of Pygmy Killer Whales (Feresa attenuata) and Melon-headed Whales (Peponocephala electra) under challenging conditions. Braz J Oceanogr. 2015;63(4):511-4.

Siciliano S, Moreno IB, Silva E. Early sightings of the Pygmy killer whale (Feresa attenuata) off the Brazilian coast: a correction to Rossi-Santos et al. (2006). Mar Biodivers Rec. 2007;1:1-3.

Stuart C, Stuart T. Field Guide to the Mammals of Southern Africa. 4th ed. South Africa: Struik Nature; 2007.

Taylor BL, Baird R, Barlow J, Dawson SM, Ford J, Mead JG, Notarbartolo di Sciara G, Wade P, Pitman RL. Feresa attenuata. The IUCN Red List of Threatened Species. 2008;e.T8551A12921135. http://dx.doi.org/10.2305/IUCN.UK.2008. RLTS.T8551A12921135.en. Downloaded on 14 May 2017.

Van Waerebeek K, Reyes JC. First record of the Pygmy killer whale, Feresa attenuata Gray, 1875 from Peru, with a summary of distribution in the eastern Pacific. Z Säugetierkunde. 1988;53:253-5.

Wang JY, Yang SC. Unusual cetacean stranding events of Taiwan in 2004 and 2005. J Cetacean Res Manag. 2006;8:283-92.

Yamada M. An account of a rare porpoise Feresa (Gray) from Japan. Sci Rep Whales Res Inst. 1954;9:59-88. 